УДК 338.4:658

\title{
АНТИКРИЗОВЕ УПРАВЛІННЯ ЯК ІНСТРУМЕНТ ЗАБЕЗПЕЧЕННЯ ЕКОНОМІЧНОЇ СТІЙКОСТІ ПІДПРИЄМСТВА В УМОВАХ ПАНДЕМІї COVID-19
}

\section{A CRISIS MANAGEMENT AS A TOOL TO ENSURE THE ECONOMIC SUSTAINABILITY OF THE ENTERPRISE IN THE CONVENTION OF THE COVID-19 PANDEMIC}

\author{
Бірбіренко Світлана Сергіївна \\ кандидат економічних наук, доцент, \\ Державний університет інтелектуальних технологій і зв'язку \\ ORCID: https://orcid.org/0000-0003-2355-4949 \\ Орлов Василь Миколайович \\ доктор економічних наук, профессор, \\ Державний університет інтелектуальних технологій і зв'язку \\ ORCID: https://orcid.org/0000-0001-6992-5500 \\ Мокруха Наталя Михайлівна \\ студентка, \\ Державний університет інтелектуальних технологій і зв'язку \\ ORCID: https://orcid.org/0000-0002-2990-5714/ \\ Birbirenko Svitlana, Orlov Vasyl, Mokrukha Natalia \\ State University of Intellectual Technologies and Communications
}

\begin{abstract}
Стаття присвячена визначенню сутності та змісту категорії «антикризове управління» як інструменту забезпечення економічної стійкості підприємства, яке функціонує у кризових умовах, спричинених впливом пандемії COVID-19. Встановлено, що наявність криз обумовлюють необхідність розробки і застосування виняткових управлінських підходів для забезпечення своєчасного початку боротьби з розвитком кризових процесів на підприємстві з метою збереження і відновлення своєї економічної стійкості. Сфрормовано авторське визначення антикризового управління економічною стійкістю підприємства. Визначено, що ефективність антикризового управління економічною стійкістю підприємства залежить від комплексності та повноти його використання, організації взаємодії усіх елементів системи управління, адекватності використовуваних методів їх оцінювання та діагностики кризових процесів.
\end{abstract}

Ключові слова: антикризове управління, економічна стійкість, пандемія COVID-19, система антикризового управління.

Статья посвящена определению сущности и содержания категории «антикризисное управление» как инструмента обеспечения экономической устойчивости предприятия, фрункционирующего в кризисных условиях, вызванных влиянием пандемии COVID-19. Установлено, что наличие кризисов обуславливает необходимость разработки и применения исключительных управленческих подходов для обеспечения своевременного начала борьбы с развитием кризисных процессов на предприятии с целью сохранения и восстановления экономической устойчивости. Предложено авторское определение антикризисного управления экономической устойчивостью предприятия. Определено, что эффрективность антикризисного управления экономической устойчивостью предприятия зависит от комплексности и полноты использования, организации взаимодействия всех элементов системы управления, адекватности используемых методов их оценки и диагностики кризисных процессов.

Ключевые слова: антикризисное управление, экономическая устойчивость, пандемия COVID-19, система антикризисного управления.

The article is devoted to defining the essence and content of the category "crisis management" as a tool to ensure the economic stability of the enterprise, which operates in crisis conditions caused by the pandemic COVID-19. It is established that the presence of crises affecting both industries and sectors of the economy, as well as individual 
enterprises necessitate the development and application of exceptional management approaches to ensure timely start of the fight against crisis processes in the enterprise to maintain and restore economic stability. The most common definitions of anti-crisis management of the enterprise of well-known authors and scientists on various aspects of economic activity and scientific works are considered. A system of anti-crisis management of economic stability of the enterprise is proposed, which allows the enterprise to react in time to any changes in the external environment. The author's definition of anti-crisis management of economic stability of the enterprise is given, the essence of which is as follows: anti-crisis management of economic stability of the enterprise is a system of methods and techniques used at the enterprise to develop measures to overcome crises, minimize negative consequences and foreign policy and restoration or increase of economic stability It is determined that anti-crisis management of economic stability of the enterprise on the one hand, is characterized as a generalized concept, which means a new direction of management science. - it is interpreted as a process that is a set of forms and methods of anti-crisis procedures for a particular enterprise in order to maintain its economic stability. Considering the terminology and many scientific articles, summarizing and analyzing different opinions and definitions of well-known authors and researchers from a different angle, it was concluded that the study of crisis management involves analysis and consideration of all factors influencing the conditions of sustainable economic development. It is established that the effectiveness of crisis management of economic stability of the enterprise depends on the complexity and completeness of its use, the organization of interaction of all elements of the management system.

Keywords: crisis management, economic stability, pandemic COVID-19, crisis management system.

Постановка проблеми. Економіка України стикнулася з невизначеністю, яка у сучасних кризових умовах обумовлюється динамічним розвитком світової та національної економіки, непередбачуваною динамікою кон'юнктури ринків, постійними законодавчими корегуванням нормативно-правової бази, стрімкою зміною життєвого циклу товарів, стрімким розвитком науково-технічного прогресу, переворотом усієї системи виробничих сил, науково-технічною революцією тощо.

У зазначених умовах незадовільні значення показників економічної стійкості підприємств свідчать про розгортання кризових процесів. Кризова ситуація, що склалася на підприємствах України пов'язана 3 пандемією COVID-19 та зумовлює зменшення обсягів виробництва, зниження інвестиційної та інноваційної активності, недолік оборотних коштів, розбалансованість фрінансових потоків, неоптимальну структуру капіталу та незадовільні зміни показників економічної стійкості.

Забезпечення економічної стійкості входить до кола найбільш стратегічно важливих завдань підприємства. Стратегія управління економічною стійкістю підприємств України, починаючи з 2019 року потребує кардинальних змін, оскільки саме з кінця 2019 року і до сьогодні відбувається негативний вплив пандемії COVID-19 на усі сорери діяльності як в Україні так і у світі.

Враховуючи вищевикладене, особливої актуальності набувають питання щодо аналізу антикризових заходів, головною метою яких $є$ підвищення економічної стійкості підприємств, які фрункціонують в умовах впливів зовнішнього фрактору - пандемії COVID-19.
Аналіз останніх досліджень і публікацій. Сучасні проблеми оцінювання економічної стійкості підприємства всесторонньо досліджуються як українськими так і зарубіжними вченими, серед яких: Ареф'єва О.В., Пілецька С.Т., Фролова Л.В., Кореніцина Т.В., Анохін С.М., Моргулець О.Б., Ячменьова В., Шевріна К.В., Іванов В.Л., Ларіна Я.С., Тхор С.А., Слупян К.В., Харитонова О.С., Оксанич Н.І., Лотоцька С.В., Олейник А.Б., Фабер Н., Шальтеггер Ш., Мюррей Е.Дж. та ін.

Вивченню економічного змісту категорій «антикризове управління» присвячена низка наукових досліджень таких вчених-економістів, як Альтман Е., Глазьєва С., Грязнова А., Іванова Г., Ковальова В., Леонтьєва В., Меншикова С., Муглер Е., Томпсон А., Уткін $€$., Яковець Ю., Юна Г., Хіт Р. та ін.

Фундаментальні дослідження економічної стійкості підприємств пов'язані, в основному, з вирішенням проблем організації фрінансовогосподарської діяльності підприємств, 3 розробкою методів стратегічного, операційного та корпоративного управління, напрямів маркетингової, інвестиційної, інноваційної політики підприємств, з обґрунтуванням системи методів і механізмів державного регулювання розвитку секторів економіки.

Таким чином, необхідність аналізу антикризового управління як інструменту забезпечення економічної стійкості підприємства, на засадах комплексної взаємодії локальних організаційно-економічних механізмів $€$ невирішеною раніше частиною загальної проблеми та обумовлює актуальність обраної теми дослідження.

Формулювання цілей статті (постановка завдання). Метою статті $€$ визначення сутності 
та змісту категорії «антикризове управління» як інструменту забезпечення економічної стійкості підприємства, яке фрункціонує у кризових умовах, спричинених впливом пандемії COVID-19.

Виклад основного матеріалу дослідження. Сучасний етап економічного розвитку України характеризується наявністю нових умов функціонування для підприємств, які відчувають на собі високий негативний вплив зовнішніх фракторів на рівень своєї економічної стійкості.

Наявність криз від яких страждають як галузі, так і сектори економіки, а також окремі підприємства обумовлюють необхідність розробки і застосування виняткових управлінських підходів для забезпечення своєчасного початку боротьби з розвитком кризових процесів на підприємстві 3 метою збереження і відновлення своєї економічної стійкості.

Сучасна економічна наука містить чимало різних теорій для пояснення причин економічних циклів та криз.

У процесі еволюції теорій криз та циклів вчені висовували дуже суперечливі погляди щодо причини економічних криз. Погляди на кризи та їх причини видозмінювалися разом зі зміною самої соціально-економічної дійсності. Так, Маркс К. вбачав причину циклічності капіталістичного відтворення в самій природі капіталізму, в протиріччі між громадським характером виробництва та приватним характером привласнення його результатів [1]. Вчений Варга $Є$. вважав, що «кризи надвиробництва, які періодично виникають, - це вибухи усіх протиріч капіталістичного суспільного устрою. Загальною причиною криз $є$ основне протиріччя між суспільним виробництвом і власно капіталістичним привласненням» [2].

На противагу цим твердженням, представники неокласичної і ліберальної шкіл не зв'язують економічні кризи з природою капіталізму, багато хто 3 них вважає причиною криз низький рівень споживання населення, що викликає надвиробництво. Узявши за основу ідею Маркса К. про зв'язок промислових коливань з періодичним оновленням основного капіталу, Туган-Барановський М. першим сфрормулював основний закон інвестиційної теорії циклів. Він вважав, що порушення ритму економічної активності приводить до кризи [3].

Тому, економічна криза - неминучий процес, різке порушення і втрата рівноваги економічної системи в наслідок диспропорцій, які в подальшому зростають, в результаті чого система переходить на новий рівень розвитку: еволюційний або інволюційний.
На сьогодні багато підприємств перебувають у важкому стані, тому однією 3 найважливіших проблем управління $€$ попередження кризових явищ та розробка заходів для виходу підприємств з кризи.

Тож, кризове явище - це стадія кризового процесу, яка проявляється за окремими напрямами фуннкціонування підприємства, не справляє відчутного впливу на порушення економічної стійкості, не має періодичності у своєму виникненні, антикризові заходи, що вживаються, забезпечують утримання економічної стійкості та подальший розвиток підприємства [4].

Вчені акцентують увагу на те, що криза це можливість, при якій можна змінити структуру виробництва, забезпечити високий рівень та темп соціально-економічного розвитку. Сучасна світова нестабільність економіки, зумовлена пандемією COVID-19, вимагає зміни характеру антикризового управління підприємством, оскільки економічний стан України наразі характеризується кризовими процесами, які характерні для сучасної світової фрінансово-економічної кризи.

У сучасній економічній літературі поняття антикризове управління тлумачиться по-різному. Розглянемо найбільш поширенні визначення антикризового управління підприємства відомих авторів та науковців з різних аспектів економічної діяльності та наукових робіт (табл. 1).

Антикризове управління економічною стійкістю підприємства необхідно розглядати як комплексну систему, яка включає зовнішнє та внутрішнє антикризове управління. Тож, узагальнюючі існуючі визначення сфрормуємо власне визначення антикризового управління економічною стійкістю підприємства: для виведення підприємства 3 кризового стану необхідно враховувати циклічність його розвитку, на який впливають цикли національної економіки в цілому, галузеві цикли та життєвий цикл продукту основного виробництва. Антикризове управління економічною стійкістю підприємства - це система методів та прийомів, які застосовуються на підприємстві для розробки заходів щодо подолання кризових ситуацій, мінімізації негативних наслідків в результаті використання наявного потенціалу, есрективної внутрішньої і зовнішньої політики та відновлення або підвищення економічної стійкості.

В Україні як і у всьому світі економічна стійкість підприємств $є$ однією $з$ найважливіших характеристик фрінансового стану підприємства. Вона відображає, наскільки підприєм- 
Таблиця 1

Поширенні визначення поняття «антикризове управління»

\begin{tabular}{|c|c|}
\hline Автор & Визначення поняття «антикризове управління» \\
\hline 1 & 2 \\
\hline Лігоненко Л. & $\begin{array}{l}\text { Антикризове управління являє собою спеціальне, постійно організоване } \\
\text { управління, націлене на найбільш оперативне виявлення ознак кризового } \\
\text { стану та створення відповідних передумов для його своєчасного } \\
\text { подолання з метою забезпечення відновлення життєздатності окремого } \\
\text { підприємства, недопущення виникнення ситуації його банкрутства [5]. }\end{array}$ \\
\hline Гайворонська Ю. & $\begin{array}{l}\text { Антикризове управління - спеціальний, комплексний процес моніторингу } \\
\text { впливу негативних чинників на діяльність підприємства з метою } \\
\text { забезпечення його постійного функціонування у зоні економічної безпеки, } \\
\text { вжиття заходів щодо попередження переходу підприємства до кризової } \\
\text { зони, а у критичних випадках - з метою його максимально швидкого та } \\
\text { ефективного виходу з кризової зони [6]. }\end{array}$ \\
\hline Ситник Л. & $\begin{array}{l}\text { Здатність розробляти оптимальні шляхи виходу з кризової ситуації, } \\
\text { визначати пріоритетні цінності підприємства в умовах кризи, координувати } \\
\text { діяльність підприємства і його працівників з передбачення кризи, } \\
\text { добиватися ефрективності їх праці в екстремальних умовах [7]. }\end{array}$ \\
\hline Нікітіна Н. & $\begin{array}{l}\text { Антикризове управління - це особливий вид управління, який здатний } \\
\text { створити умови режиму стійкого функціонування підприємства на основі } \\
\text { розробленої антикризової орінансової політики, що дає змогу своєчасно } \\
\text { реагувати на перші ознаки появи кризової ситуації [8]. }\end{array}$ \\
\hline Уткін $€$. & $\begin{array}{l}\text { Управління, спрямоване на попередження можливих ускладнень у } \\
\text { ринковій діяльності підприємства, забезпечення його стабільного } \\
\text { господарювання з орієнтацією розширеного відновлення на сучаснішій } \\
\text { основі та власних заощадженнях [9]. }\end{array}$ \\
\hline $\begin{array}{c}\text { Мінаєв } € ., \\
\text { Панагушин В. }\end{array}$ & $\begin{array}{l}\text { Під антикризовим управлінням слід розуміти не тільки управління, } \\
\text { орієнтоване на виведення підприємства зі стану кризи, а й управління, } \\
\text { яке має заздалегідь спрогнозувати та попередити неплатоспроможність } \\
\text { підприємства згідно з виробленою програмою підвищення конкурентних } \\
\text { переваг фрінансового оздоровлення [10]. }\end{array}$ \\
\hline Сметанюк О. & $\begin{array}{l}\text { Система управлінських заходів та рішень з діагностики, попередження, } \\
\text { нейтралізації і подолання кризових явищ та їхніх причин за умов } \\
\text { мінімізації втрат та негативних наслідків. Основою антикризового } \\
\text { управління є саме попередження кризових ситуацій, тому будь-яке } \\
\text { управління повинне мати антикризовий характер [11]. }\end{array}$ \\
\hline Нечай М. & $\begin{array}{l}\text { Антикризове управління, можна визначити як особливу цілісну комплексну } \\
\text { модель превентивного управління, що включає вбудовану систему } \\
\text { моніторингу зовнішнього і внутрішнього середовища фрункціонування } \\
\text { підприємства в цілому і його структурних елементів і своєчасного запобігання } \\
\text { ризикам з метою нейтралізації або пом'якшення кризових ситуацій [12]. }\end{array}$ \\
\hline Іванюта С. & $\begin{array}{l}\text { Антикризове управління - це система організаційно-економічних заходів } \\
\text { з діагностики, попередження, нейтралізації і подолання кризових явищ та } \\
\text { причин їх виникнення в економічних системах на всіх рівнях економіки [13]. }\end{array}$ \\
\hline $\begin{array}{c}\text { Холод 3., } \\
\text { Штангрет } 3 .\end{array}$ & $\begin{array}{l}\text { Антикризове управління - це система управління підприємством, } \\
\text { спрямована на випереджальне виявлення можливих кризових ситуацій, } \\
\text { розробку заходів протидії, швидкого реагування на будь-які зміни у } \\
\text { зовнішньому і внутрішньому середовищі [14]. }\end{array}$ \\
\hline
\end{tabular}

Джерело: [5-14]

ство стабільне, незалежне від зовнішніх кредиторів, наскільки власники фрінансують своє підприємство, яка частина власного капіталу використовується для фрінансування поточної діяльності. Тому і повстає проблема аналізу економічної стійкості будь-якого підприємства, бо за допомогою цього аналізу можна виявити сильні і слабкі позиції різних підприємств.
У 2020 році одним 3 головних чинників впливу на економічні процеси виявився фрактор розповсюдження пандемії COVID-19. У відповідь на пандемію COVID-19 відбулись суттєві зміни у життєдіяльності багатьох держав світу, у тому числі і в Україні. Так, було запроваджено надзвичайний стан в цілому в країнах або в окремих регіонах чи сорерах [15]. 
Пандемія гострої респіраторної хвороби COVID-19, спричиненої коронавірусом SARSCoV-2, стала тим фрактором, який змусив весь світ переглянути не лише свої прогнози розвитку, свою короткострокову економічну та соціальну політику, але і по іншому підійти до формування власних пріоритетів на довгостроковий період.

Проаналізувавши результати діяльності підприємств України в період поширення коронавірусної інфекції, важливість механізму формування економічної стійкості підприємства набуває особливої актуальності. Так, згідно [15] якщо: у промисловості падіння виробництва у квітні 2020 року до квітня 2021 року становило 16,2\%, то вже у травні - на $12,2 \%$ та у червні - на 5,6\% відповідно; у сорері вантажних перевезень: вантажообіг у квітні скоротився на 27,2\%, то вже у травні - на $26 \%$ та у червні - на 18,3\% відповідно; пасажирообіг у квітні скоротився на 95,9\%, то вже у травні - на 92,3\% та у червні - на $72 \%$ відповідно. У цілому упродовж січня-червня 2020 р. серед основних секторів економіки відбулося зростання лише обсягу обороту роздрібної торгівлі - на 3,0\% (зростання на 10,5\% у січні-червні 2019 року). Водночас інші види економічної діяльності показали скорочення: сільське господарство - на 18,7\% (зростання на 5,8\% у січні-червні 2019 року); обсяг вантажообігу - на 19,6\%, обсяг пасажирообігу на 55,9\%; оптовий товарооборот - на 0,5\%;

\section{Система антикризового управління економічною стійкістю підприємства}

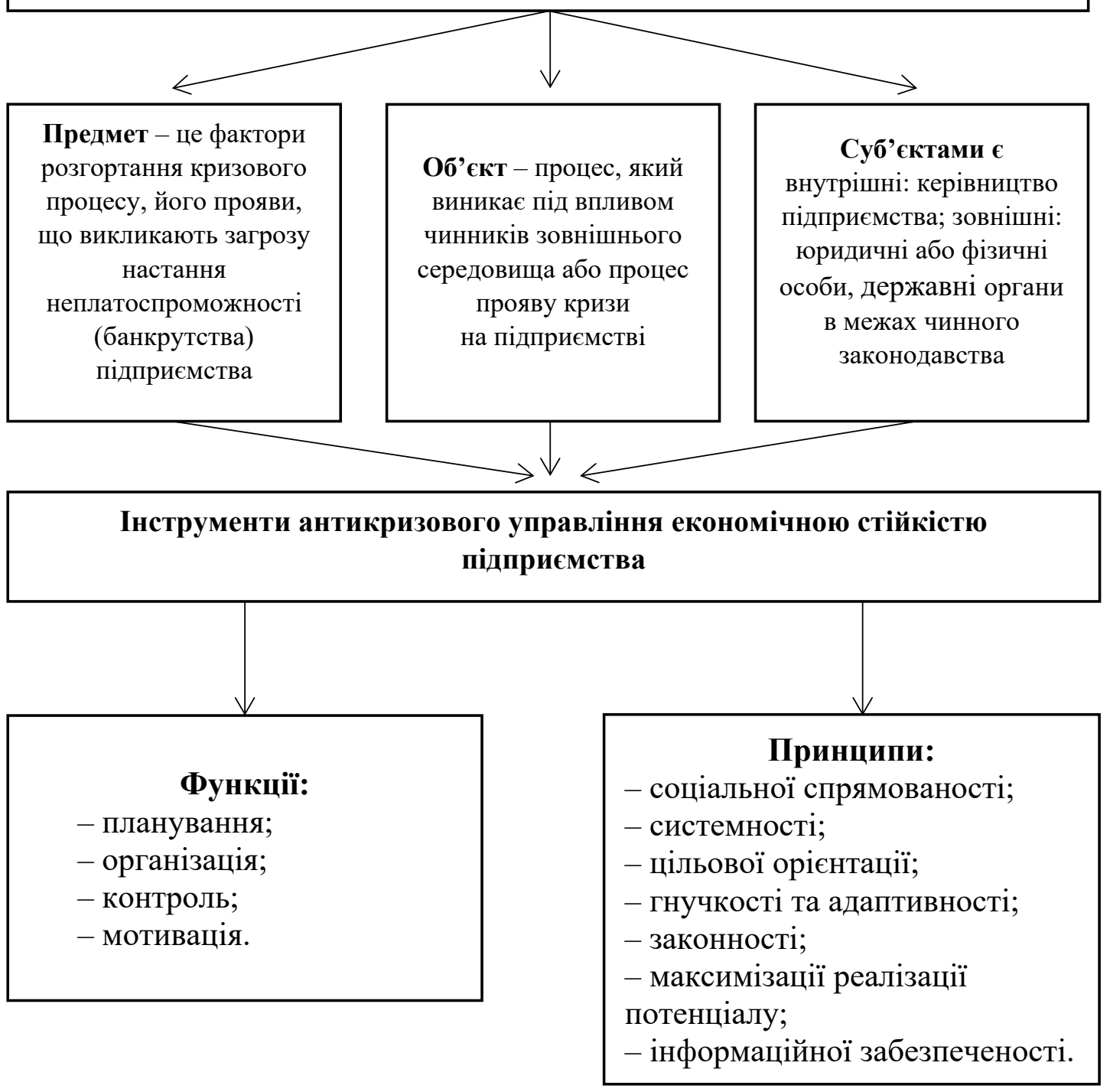

Рис. 1. Система антикризового управління економічною стійкістю підприємства Джерело: власна розробка авторів 
промислове виробництво - на 8,3\%; будівництво - на $5,5 \%$.

Таким чином, для забезпечення антикризового управління економічною стійкістю в залежності від стадії кризового процесу, підприємство має орормувати систему антикризового управління економічною стійкістю підприємства, яка дає змогу підприємству вчасно зреагувати на будь-які зміни зовнішнього середовища (рис. 1). Таким чином, система антикризового управління економічною стійкістю підприємства - це сукупність взаємопов'язаних заходів організаційно-правового характеру, спрямованих, з одного боку, на профрілактику розвитку ознак кризових процесів під впливом зовнішнього та внутрішнього середовища, розробку заходів щодо загострення кризових процесів унаслідок результативного використання його потенціалу, ефективною внутрішньою і зовнішньою політикою, що дає змогу вийти на новий рівень розвитку 3 найменшими негативними наслідками та забезпечити економічну стійкість, а з іншого - у разі абсолютної збитковості підприємства - на проведення передбачених чинним законодавством відповідних процесів і процедур [14].

Отже, з'являється антикризове управління економічною стійкістю підприємства, що 3 одного боку, характеризується як узагальнене поняття, яке означає новий напрям управлінської науки, пов'язаний з вивченням методів та прийомів, які дають змогу запобігти банкрутству, з іншого - воно трактується як процес, що є сукупністю фрорм і методів реалізації антикризових процедур стосовно конкретного підприємства з метою збереження його економічної стійкості.
У свою чергу, ефективність антикризового управління економічною стійкістю підприємства залежить від комплексності та повноти його використання, організації взаємодії усіх елементів системи управління, адекватності використовуваних методів їх оцінювання та діагностики кризових процесів.

Висновки. Отже, поняття антикризове управління має досить багато визначень та безпосередньо має пересічне значення при формуванні історично-дослідницьких та сучасних підходів та напрямів. Сучасний етап економічного розвитку України зумовив формування нових, специфрічних умов функціонування підприємств, які характеризуються високим негативним рівнем впливу зовнішніх чинників на економічну стійкість підприємств. Системні, структурні кризи, від яких страждають як окремі підприємства, так і цілі галузі і сектори економіки, змушують розробляти і застосовувати особливі управлінські підходи, які забезпечують своєчасний початок боротьби з розвитком кризових процесів на підприємстві.

Розглянувши термінологію та безліч наукових статей, підсумовуючи та проаналізувавши різні думки і визначення відомих авторів та дослідників під іншим кутом зору, можна зробити висновок, що дослідження антикризового управління передбачає аналіз та врахування усіх фракторів, які впливають на фрормування умов стійкого економічного розвитку підприємства та країни взагалі.

Тож, ефрективність антикризового управління економічною стійкістю підприємства залежить від комплексності та повноти його використання, організації взаємодії усіх елементів системи управління.

\section{СПИСОК ВИКОРИСТАНИХ ДЖЕРЕЛ:}

1. Маркс К. Капитал. В 3-х томах. Москва : ГИПЛ, 1955. 2230 с.

2. Варга Є.С. Экономические кризисы / За ред. В. Я. Аболтіна. Москва : Наука, 1974. 432 с.

3. Туган-Барановський М.І. Промышленные кризисы. Очерк из социальной истории Англии. Київ : Наукова думка, 2004. 368 с.

4. Надьон Г.О. Криза в діяльності підприємства: діагностика та подолання : монографрія. Луганськ : СНУ ім. В. Даля, 2010. 384 c.

5. Лігоненко Л.О. Антикризове управління підприємством: теоретико-методолгічні засади та практичний інструментарій : монограсрія. КНТЕУ, 2001. 580 с.

6. Гайворонська Ю.Є. Методичні основи функціонування механізму антикризового управління підприємством : автореф. дис. канд. екон. наук : спец. 08.06.01. НТУ, 2006. 21 с.

7. Ситник Л.С. Організаційно-економічний механізм антикризового управління підприємством : монограсрія. Донецьк : IЕП НАН України, 2000. 504 с.

8. Нікітіна Н.В. Антикризисное финансовое управление промышленным предприятием: теория, методология, практика контролинга : авторефр. дис. д-ра экон. наук : спец. 08.00.10. Саранск : ГОУВПО «Мордовский государственный университет им. Н.П. Огарева», 2009. 30 с. 
9. Уткін Є. Антикризисное управление. Тандем. Київ : ЭКМОС, 1997. 400 с.

10. Мінаєв Є., Панагушин В.П. Антикризисное управление. Приор, 1998. 432 с.

11. Сметанюк О.А. Діагностика фінансового стану підприємства в системі антикризового управління : автореср. дис. канд. екон. наук : спец. 08.06.01. Хмельницький : ХНУ, 2006. 20 с.

12. Нечай М.Г. Антикризисное управление финансовой устойчивостью предприятий с учётом внешних и внутренних фракторов : автореф. дис. канд. екон. наук : спец. 08.00.10. Томск : ГОУВПО «Томский государственный университет», 2009. 26 с.

13. Іванюта С.М. Антикризове управління в аграрній сфері контролінгу : авторефр. дис. д-ра екон. наук : спец. 08.06.01. Українська академія аграрних наук, 2006. 20 с.

14. Холод 3.М., Штангрет 3.М. Методологічні аспекти антикризового управління. Економіка промислоBості. 2002. № 2. C. 32-40.

15. Міністерство розвитку економіки, торгівлі та сільського господарства України. Україна: вплив COVID-19 на економіку і суспільство. Департамент стратегічного планування та макроекономічного прогнозування. 2020. № 52.

\section{REFERENCES:}

1. Marks K. (1955) Kapital. V 3-kh tomakh [Capital. In 3 volumes]. Moscow: GIPL, 2230 p. (in Russian)

2. Varha Ye.S. (1974) Ekonomicheskie krizisy [Economic crises]. Moscow: Nauka, 432 p. (in Russian)

3. Tuhan-Baranovskyi M.I. (2004) Promyshlennye krizisy. Ocherk iz socialnoj istorii Anglii [Industrial crises. An outline of the social history of England]. Kyiv: Naukova dumka, 368 p. (in Russian)

4. Nadon H.O. (2010) Kryza v diialnosti pidpryiemstva: diahnostyka ta podolannia [Crisis in the enterprise: diagnosis and overcoming]: monohrafiya [a monograph]. Lugansk: SNO named after V. Dahl, 384 p. (in Ukrainian)

5. Lihonenko L.O. (2001) Antykryzove upravlinnia pidpryiemstvom: teoretyko-metodolhichni zasady ta praktychnyi instrumentarii [Anti-crisis management of the enterprise: theoretical and methodological principles and practical tools]: monohrafiya [a monograph]. Kyiv: KNTEU, 580 p. (in Ukrainian)

6. Haivoronska Yu.le. (2006) Metodychni osnovy funktsionuvannia mekhanizmu antykryzovoho upravlinnia pidpryiemstvom [Methodical bases of functioning of the mechanism of anti-crisis management of the enterprise]. Extended abstract of Candidate's thesis. Kyiv. (in Ukrainian)

7. Sytnyk L.S. (2000) Orhanizatsiino-ekonomichnyi mekhanizm antykryzovoho upravlinnia pidpryiemstvom [Organizational and economic mechanism of crisis management of the enterprise]: monohrafiya [a monograph]. Donetsk: IEP NAS of Ukraine, 504 p. (in Ukrainian)

8. Nikitina N.V. (2009) Antikrizisnoe finansovoe upravlenie promyshlennym predpriyatiem: teoriya, metodologiya, praktika kontrolinga [Crisis financial management of an industrial enterprise: theory, methodology, practice of controlling]. Extended abstract of Doctor's thesis. Saransk. (in Russian)

9. Utkin Ye. (1997) Antikrizisnoe upravlenie. Tandem [Crisis management. Tandem]. Kyiv: EKMOS, 400 p. (in Russian)

10. Minaiev Ye., Panahushyn V.P. (1998) Antikrizisnoe upravlenie [Crisis management]. Prior, 432 p. (in Russian)

11. Smetaniuk O.A. (2006) Diahnostyka finansovoho stanu pidpryiemstva v systemi antykryzovoho upravlinnia [Diagnosis of the financial condition of the enterprise in the crisis management system]. Extended abstract of Candidate's thesis. Khmelnytskyi. (in Ukrainian)

12. Nechaj M.G. (2009) Antikrizisnoe upravlenie finansovoj ustojchivostyu predpriyatij s uchyotom vneshnih i vnutrennih faktorov [Crisis management of the financial stability of enterprises, taking into account external and internal factors]. Extended abstract of Candidate's thesis. Tomsk. (in Russian)

13. Ivaniuta S.M. (2006) Antykryzove upravlinnia v ahrarnii sferi kontrolinhu [Crisis management in the agricultural sphere of controlling]. Extended abstract of Doctor's thesis. Kyiv. (in Ukrainian)

14. Kholod Z.M. \& Shtanhret Z.M. (2002) Metodolohichni aspekty antykryzovoho upravlinnia [Methodological aspects of crisis management]. Ekonomika promyslovosti, no. 2, pp. 32-40.

15. Ministry of Economic Development, Trade and Agriculture of Ukraine (2020) Ukraina: vplyv COVID-19 na ekonomiku i suspilstvo [Ukraine: the impact of COVID-19 on the economy and society]. Departament stratehichnoho planuvannia ta makroekonomichnoho prohnozuvannia, no. 52. 